\title{
Effect of Legume Fodder Intercrops and Different Fertilizer Levels on Growth, Yield and Economics of Bt Cotton under Irrigated Condition
}

\author{
M. Daisy*, K. Rajendran and M. Mohamed Amanullah \\ Department of Agronomy, Tamil Nadu Agricultural University, Coimbatore-3, \\ Tamil Nadu, India \\ *Corresponding author
}

\begin{abstract}
A B S T R A C T
Cotton (Gossypium hirsutum L.) is the most important cash crop and there is a demand for simultaneous increase in the productivity of cotton, edible oilseeds and fodders to fulfil the diversified needs of growing population. For this purpose, cotton-based intercropping seems to be a promising strategy. Short duration legume fodders are potential sources of

\section{Keywords}

Legume fodder intercropping,

Seed cotton yield, Green fodder yield, Net income, Benefit cost ratio.

Article Info

Accepted: 26 June 2017 Available Online: 10 July 2017 nutrients during summer especially atmospheric nitrogen fixing which are supplement of inorganic fertilizers. A field experiments was conducted to investigate the relative performance of legume fodder intercropping system on productivity of $\mathrm{Bt}$ cotton with different fertilizer levels during the Kharif season of 2015-2016 and 2016-2017. The experiment was laid out in split plot design with five main plots $\left(\mathrm{C}_{1}\right.$-Cotton; $\mathrm{C}_{2}$ Cotton+Fodder Cowpea; $\mathrm{C}_{3^{-}}$Cotton+ Horse gram; $\mathrm{C}_{4^{-}}$Cotton+Moth bean; $\mathrm{C}_{5^{-}}$ Cotton+Pillipesara) and three subplots $\left(\mathrm{F}_{1}-100 \%\right.$ RDF (120:60:60 kg NPK ha $\left.{ }^{-1}\right) ; \mathrm{F}_{2}-125 \%$ RDF (150:75:75 kg NPK ha $\left.{ }^{-1}\right) ; F_{3}-150 \%$ RDF (180:90:90 kg NPK ha $\left.{ }^{-1}\right)$. Bt cotton + moth bean $\left(\mathrm{C}_{4}\right)$ fodder intercropping system recorded significantly higher seed cotton yield during both years $\left(2029 \mathrm{~kg} \mathrm{ha}^{-1}\right.$ and $\left.1507 \mathrm{~kg} \mathrm{ha}^{-1}\right)$ followed by Bt cotton + horse gram $\left(\mathrm{C}_{3}\right)$ with $1909 \mathrm{~kg} \mathrm{ha}^{-1}$ and $1422 \mathrm{~kg} \mathrm{ha}^{-1}$ during both years. Among legume fodder, fodder cowpea intercropped with Bt cotton with $150 \%$ RDF $\left(\mathrm{C}_{2} \mathrm{~F}_{3}\right)$ produced higher green fodder yield 17,407 and $14,431 \mathrm{~kg} \mathrm{ha}^{-1}$ during first and second year study. Highest net income of ₹ 98888 and ₹ 65922 ha $^{-1}$ was recorded in Bt cotton + fodder cowpea $\left(\mathrm{C}_{2}\right)$ system and was followed by Bt cotton + moth bean $\left(\mathrm{C}_{4}\right)$ and Bt cotton + horse gram $\left(\mathrm{C}_{3}\right)$ intercropping system. But the highest benefit cost ratio was in Bt cotton + moth bean $\left(\mathrm{C}_{4}\right)$ of 2.55 and 2.14 followed by Bt cotton + fodder cowpea $\left(\mathrm{C}_{2}\right)$ of 2.52 and 2.04 during first and second year, respectively.
\end{abstract}

\section{Introduction}

Cotton is known as white gold and queen of fibres and it is an important cash crop of global significance which plays a dominant role in world agriculture and industrial economy. It is one of the important cash crop for Indian farmer and contributes around 30 per cent to gross domestic product of Indian agriculture. Mono-cropping, erratic rainfall, poor soils, continuous use of inorganic fertilizers without application of organic manures and increased sucking pests are reduced its productivity. In this situation to ward off these problems, it's an option to grow compatible short duration intercrops to best utilize the wide space between cotton crop (Ramanjaneyalu and Reddy, 2002). Low 
production of cotton in India is mainly due to 80 per cent of cultivable area is under rainfed condition with vagaries of monsoon. Cotton growers face major problem of increase in production cost especially fertilizer is an important input which raises production cost.

Legumes play a vital role in contributing to food security, income generation and maintenance of environment for small-scale farmers. Legume intercrops are included in cropping system due to their ability to reduce soil erosion, improving land productivity through soil amelioration, suppress weeds and fix nitrogen. In India annual cotton is commonly intercropped with wheat, maize and cowpea.

The competitive effect of short duration cowpea when intercropped with cotton, the cotton yield has decreased because of competition effect and the loss was compensated to varying degrees by the yield of the legume intercrops. Rochester et al., (2001) studied the contribution of legume crops such as faba bean (Vicia faba), field pea (Pisum sativaum) and lab-lab (Lablab purpureus) on nitrogen fertility of cotton cropping system.

Short duration legume forages and tree fodders are potential sources of nutrients during summer especially atmospheric nitrogen fixing which are supplement of inorganic fertilizers. Enhancement of cotton is also possible by intercropping with a short duration legume and other leguminous fodder crops due to their complementary effect, harvesting at short duration and intercropping at optimum ratio have the least smothering effect, which would favour for succeeding crop. Its values lies in, high protein content, ability to tolerate drought condition, faster growth and the capacity of fixing atmospheric nitrogen. Based on this background the present study has formulated in order to develop a compatible, short duration legume fodder to cotton facilitating legume fodder intercropping system without affecting the productivity of cotton at large scale which makes the system more feasible, productive and economical.

\section{Materials and Methods}

A field experiments was conducted to study the effect of legume fodder intercropping system on productivity of $\mathrm{Bt}$ cotton with various fertilizer levels during the Kharif season of August 2015 to February 2016 at Krishi Vigyan Kendra, Veterinary College and Research Institute campus, Namakkal. Soil $\mathrm{pH}$ was 8.1 and available $\mathrm{N}, \mathrm{P}$ and $\mathrm{K}$ were 251.5 and 9.7 and $79.0 \mathrm{~kg} \mathrm{ha}^{-1}$ during first year study, respectively. The experiment was laid out in split plot design with five main plots $\left(\mathrm{C}_{1}\right.$-Cotton; $\mathrm{C}_{2}$-Cotton+Fodder Cowpea; $\mathrm{C}_{3}$ - Cotton+ Horse gram; $\mathrm{C}_{4}$-Cotton+Moth bean; $\mathrm{C}_{5}$-Cotton+Pillipesara) and three subplots $\left(\mathrm{F}_{1}-100 \%\right.$ RDF (120:60:60 kg NPK $\left.\mathrm{ha}^{-1}\right) ; \mathrm{F}_{2}-125 \%$ RDF (150:75:75 kg NPK ha ${ }^{-}$ $\left.{ }^{1}\right) ; \mathrm{F}_{3}-150 \% \operatorname{RDF}\left(180: 90: 90 \mathrm{~kg}\right.$ NPK ha $\left.{ }^{-1}\right)$. The treatments were replicated thrice. Application of organic manure was done through farmyard manure (FYM) @ 12.5 tones ha ${ }^{1}$ before last harrowing before sowing of kharif crops. Complete dose of $\mathrm{P}$ applied as basal dose. $\mathrm{N}$ applied in three equal split doses viz., Basal, 45 DAS and 65 DAS. K applied as half of the dose as basal and remaining half at 45 DAS. In case of intercropping treatments, the general recommended dose of fertilizer of base crop was applied. Spacing allotted for cotton and intercrops were $120 \times 60 \mathrm{~cm}$ and $30 \times 15 \mathrm{~cm}$ respectively. Package of practices were followed as per the recommendation of crop production guide 2012.

Legume fodder harvested at 55 DAS as green fodder and observations recorded on growth and yield parameters of both cotton and fodder; dry matter production; physiological parameters like LAI, CGR, RGR and NAR 
and quality parameter like lint index, seed index, micronaire, fineness and fiber strength. The plant population was maintained by gap filling and subsequent thinning carried out and keeping single plant hill ${ }^{-1}$. Two hoeing and two hand weeding were done to keep crop-weed free and conserve soil moisture. Monocrotophos and Endosulphan (35 EC) were sprayed twice to protect crop from sucking pest. Observations were recorded as per the established norms. Lint yield was calculated by ginning percentage multiply with seed-cotton yield and divided by 100 . The seed cotton from each net plot was picked and the same weighed separately at each picking. The total yield was work out by summation of quantity of seed cotton picked in all pickings. Plot wise data on soil nutrient content and yield etc. was subjected to statistical analysis by statistical method. Economic parameters like cost of cultivation, gross return, net return and benefit-cost ratio were worked out to assess the economic feasibility of intercropping concept.

\section{Results and Discussion}

\section{Growth attributes}

In this experiment, intercropping with different crops shows that growth attributes (Table 1) viz. (plant height, number of sympodial, number of functional leaves and total dry matter accumulation) of cotton were influenced significantly but number of sympodial and leaf area index of cotton were not influenced significantly. Higher plant height $(151.0 \mathrm{~cm}$ and $112.4 \mathrm{~cm})$ was recorded in Sole $\mathrm{Bt}$ cotton system than other intercropping system. Ravindra Kumar et al., (2017) reported that tallness of cotton plants in the plots of intercrops and then sole cotton was might be associated with competitive effect for space, moisture, nutrient and light (due to Annidation process) further accelerated the phototropism and thereby increased plant height of cotton.
The maximum number of sympodial branches plant $^{-1}$ (32.33 and 24.18), maximum dry matter production (6167 and $5861 \mathrm{~kg} \mathrm{ha}^{-1}$ ) and leaf area index (3.03 and 1.96) were recorded in cotton + moth bean intercropping system than other cropping system and Bt cotton pure stand during both years of study. Applied nutrients might have favoured the more profuse vegetative growth by directly increasing the leaf area. Increase in nitrogen levels could also be responsible for increased in leaf area in cotton as observed by Kumara Perumal (1999). The increased drymatter accumulation with increase in nitrogen application might be due to the fact that nitrogen fertilization made the plants more efficient in photosynthetic activity by enhancing the carbohydrate metabolism resulting in increased drymatter accumulation. The increase in plant drymatter production in response to higher levels of nitrogen was in confirmity with the earlier findings of Ram Prakash et al., (2001), Sagarka et al., (2002), Giri and Gore (2006) and Sunitha et al., (2010).

\section{Yield attributes}

Legume fodder intercropping with different fertilizer levels showed that yield and yield attributes viz. (crop growth rate, (CGR), number of bolls, number of fruiting points and seed cotton yield) of Bt cotton were influenced significantly by the treatment imposed during both years of study. Bt cotton + moth bean $\left(\mathrm{C}_{4}\right)$ recorded significantly higher values (Table 2) of yield attributes than the rest of the intercrops viz., fodder cowpea, horse gram and pillipesera and Bt cotton pure stand. It recorded the highest CGR value of (5.92 and 6.08), number of bolls (60.67 and 48.33), number of fruiting points (78.33 and 70.97) and seed cotton yield (2029 and 1507). It was on par with $\mathrm{Bt}$ cotton + horse gram $\left(\mathrm{C}_{3}\right)$ intercropping system but CGR values recorded the on par with $\mathrm{Bt}$ cotton + fodder cowpea $\left(\mathrm{C}_{2}\right)$ due to its fast growing nature. 
Table.1 Effect of legume fodder intercropping systems and different fertilizer levels on growth Parameters of Bt cotton at 120 DAS

2015-2016

Treatments Fod

Fodder intercropping systems

\begin{tabular}{ccccccccc}
\hline $\mathbf{C}_{\mathbf{1}}$ & 151.0 & 28.67 & 5783 & 2.66 & 112.4 & 22.34 & 5611 & 1.58 \\
$\mathbf{C}_{\mathbf{2}}$ & 149.8 & 23.33 & 4679 & 2.76 & 107.1 & 20.98 & 4287 & 1.73 \\
$\mathbf{C}_{\mathbf{3}}$ & 141.7 & 30.33 & 5722 & 2.81 & 106.8 & 22.67 & 5256 & 1.52 \\
$\mathbf{C}_{\mathbf{4}}$ & 147.6 & 32.33 & 6167 & 3.03 & 105.1 & 24.18 & 5861 & 1.96 \\
$\mathbf{C}_{\mathbf{5}}$ & 145.0 & 28.67 & 5598 & 3.61 & 103.6 & 22.02 & 5347 & 1.50 \\
\hline $\mathbf{S E d}$ & 5.61 & 0.76 & 215 & 0.09 & 2.8 & 0.58 & 169 & 0.04 \\
$\mathbf{C D}(\mathbf{P}=\mathbf{0 . 0 5})$ & 12.94 & 1.75 & 496 & 0.20 & 6.4 & 1.34 & 390 & 0.10 \\
\hline Different fertilizer levels & & & & & & & \\
\hline $\mathbf{F}_{\mathbf{1}}$ & 132.0 & 26.40 & 5299 & 2.65 & 101.2 & 20.35 & 4954 & 1.38 \\
$\mathbf{F}_{\mathbf{2}}$ & 147.6 & 29.60 & 5543 & 2.78 & 105.9 & 22.65 & 5339 & 1.62 \\
$\mathbf{F}_{\mathbf{3}}$ & 161.4 & 30.40 & 5928 & 2.89 & 113.7 & 24.31 & 5525 & 1.97 \\
\hline $\mathbf{S E d}$ & 5.0 & 0.43 & 192 & 0.09 & 1.9 & 0.40 & 229 & 0.03 \\
$\mathbf{C D}(\mathbf{P = 0 . 0 5})$ & 10.4 & 0.89 & 402 & 0.18 & 4.1 & 0.84 & 478 & 0.06 \\
\hline
\end{tabular}

Table.2 Effect of legume fodder intercropping systems and different fertilizer levels on yield Attributes and yield of Bt cotton at 120 DAS

\begin{tabular}{ccccccccc}
\hline & \multicolumn{9}{c}{$\mathbf{2 0 1 5 - 2 0 1 6}$} & \multicolumn{4}{c}{$\mathbf{2 0 1 6 - 2 0 1 7}$} \\
\cline { 2 - 9 } Treatments & CGR & $\begin{array}{c}\text { No. of } \\
\text { bolls }\end{array}$ & $\begin{array}{c}\text { No. of } \\
\text { fruiting } \\
\text { points }\end{array}$ & $\begin{array}{c}\text { Seed } \\
\text { cotton } \\
\text { yield }\end{array}$ & CGR & $\begin{array}{c}\text { Number } \\
\text { of bolls }\end{array}$ & $\begin{array}{c}\text { No. of } \\
\text { fruiting } \\
\text { points }\end{array}$ & $\begin{array}{c}\text { Seed } \\
\text { cotton } \\
\text { yield }\end{array}$ \\
\hline Fodder intercropping systems & & & & & & \\
\hline $\mathbf{C}_{\mathbf{1}}$ & 5.43 & 50.00 & 72.00 & 1856 & 5.48 & 41.29 & 61.07 & 1371 \\
$\mathbf{C}_{\mathbf{2}}$ & 4.24 & 45.67 & 66.00 & 1674 & 4.29 & 36.82 & 56.74 & 1228 \\
$\mathbf{C}_{\mathbf{3}}$ & 5.02 & 56.33 & 74.60 & 1909 & 5.19 & 42.66 & 64.54 & 1422 \\
$\mathbf{C}_{\mathbf{4}}$ & 5.92 & 60.67 & 78.33 & 2029 & 6.08 & 48.33 & 70.97 & 1507 \\
$\mathbf{C}_{\mathbf{5}}$ & 5.05 & 51.00 & 69.66 & 1730 & 5.69 & 39.34 & 58.60 & 1288 \\
\hline $\mathbf{S E d}$ & 0.16 & 1.54 & 2.01 & 39 & 0.17 & 1.12 & 3.76 & 40 \\
$\mathbf{C D}(\mathbf{P = 0 . 0 5})$ & 0.33 & 3.56 & 4.63 & 90 & 0.39 & 2.57 & 8.67 & 92 \\
\hline Different fertilizer levels & & & & & & & \\
\hline $\mathbf{F}_{\mathbf{1}}$ & 4.92 & 48.40 & 69.98 & 1742 & 4.92 & 36.01 & 59.08 & 1266 \\
$\mathbf{F}_{\mathbf{2}}$ & 4.98 & 52.00 & 71.98 & 1786 & 5.47 & 42.09 & 63.71 & 1350 \\
$\mathbf{F}_{\mathbf{3}}$ & 5.49 & 57.80 & 74.40 & 1991 & 5.63 & 46.96 & 64.37 & 1474 \\
\hline$\quad \mathbf{S E d}$ & 0.22 & 0.76 & 3.76 & 46 & 0.22 & 0.80 & 2.05 & 41 \\
$\mathbf{C D}(\mathbf{P = 0 . 0 5})$ & 0.46 & 1.60 & 8.67 & 95 & 0.45 & 1.67 & 4.28 & 85 \\
\hline
\end{tabular}


Table.3 Cost of cultivation, gross return, net return and B: C ratio as influenced by legume Fodder intercropping systems and different fertilizer levels in Bt cotton

\begin{tabular}{|c|c|c|c|c|c|c|c|c|}
\hline \multirow[b]{2}{*}{ Treatments } & \multicolumn{4}{|c|}{ 2015-2016 } & \multicolumn{4}{|c|}{ 2016-2017 } \\
\hline & $\begin{array}{c}\text { Cost } \\
\text { cultivation }\end{array}$ & $\begin{array}{c}\text { Gross } \\
\text { return }\end{array}$ & $\begin{array}{c}\text { Net } \\
\text { return }\end{array}$ & $\begin{array}{l}\text { B: C } \\
\text { Ratio }\end{array}$ & $\begin{array}{c}\text { Cost } \\
\text { cultivation } \\
\end{array}$ & $\begin{array}{c}\text { Gross } \\
\text { Return }\end{array}$ & $\begin{array}{c}\text { Net } \\
\text { Return }\end{array}$ & $\begin{array}{l}\text { B: C } \\
\text { Ratio }\end{array}$ \\
\hline \multicolumn{9}{|c|}{ Legume fodder intercropping systems } \\
\hline $\mathbf{C}_{1}$ & 60432 & 102098 & 41666 & 1.69 & 56646 & 75426 & 18780 & 1.33 \\
\hline $\mathbf{C}_{2}$ & 64932 & 163820 & 98888 & 2.52 & 62996 & 128918 & 65922 & 2.04 \\
\hline $\mathbf{C}_{3}$ & 60732 & 118954 & 58222 & 1.95 & 53806 & 90621 & 37672 & 1.68 \\
\hline $\mathbf{C}_{4}$ & 58892 & 149920 & 91028 & 2.55 & 52949 & 113489 & 59710 & 2.14 \\
\hline $\mathbf{C}_{5}$ & 61232 & 101069 & 39837 & 1.65 & 56779 & 74403 & 17624 & 1.31 \\
\hline \multicolumn{9}{|c|}{ Different fertilizer levels } \\
\hline $\mathbf{F}_{1}$ & 57072 & 119520 & 62448 & 2.09 & 54802 & 86450 & 31361 & 1.57 \\
\hline $\mathbf{F}_{2}$ & 61711 & 122719 & 61009 & 1.98 & 55883 & 95704 & 39334 & 1.71 \\
\hline $\mathbf{F}_{3}$ & 64951 & 139279 & 74328 & 2.14 & 59221 & 107559 & 47331 & 1.83 \\
\hline
\end{tabular}

CGR values, after 45 days was increased in intercropping system might be attributed to the fact, that availability of nutrients through higher fertilizer levels at critical stages and also nutrients received from root nodules of legume crops after 55 DAS might increase the leaf production of cotton. Before canopy covers, achieves full interception of light, the variation in leaf area is a powerful determinant for variation in crop growth (Gifford and Jenkins 1981). Boll retention in terms of boll number was influenced by combined factors that involve nutrition, hormones, field environment and weather conditions prevailed during cropping season (Guinn, 1982) and Sreenivas and Rao (1999). The hormonal effect might have increased with enhanced fertilizer application. This could have improved the boll retention by increased fertility co-efficient (Bhatt et al., 1982).

The highest seed cotton yield under intercropping system might be due to the application of enhanced fertilizer, which increased, the growth, DMP, number of fruiting points, number of bolls and ultimately the yield. This agrees with the findings of Kumaraswamy and Hosmani (1978); Ram Prakash and Mangal Prasad (2000). Further it was observed that increase in $\mathrm{N}$ level resulted in increased $\mathrm{N}$ uptake due to increased seed cotton yield.

\section{Economics}

Perusal of data showed (Table 3) with respect to intercropping system, the maximum gross income of ₹ 163820 and ₹ $128918 \mathrm{ha}^{-1}$ was realized in Bt cotton + fodder cowpea $\left(\mathrm{C}_{2}\right)$ and it was closely followed by $\mathrm{Bt}$ cotton + moth bean $\left(\mathrm{C}_{4}\right)$ ( $₹ 149920$ and $₹ 113489$ ha $^{-1}$ during first and second year, respectively). Highest net income of ₹ 98888 and ₹ $65922 \mathrm{ha}^{-1}$ was also recorded under Bt cotton + fodder cowpea $\left(\mathrm{C}_{2}\right)$ system. But the highest benefit cost ratio was in Bt cotton + moth bean $\left(\mathrm{C}_{4}\right)$ (2.55 and 2.14 during) first and second year study. This was mainly due higher green fodder yield of fodder cowpea and higher price fetched by green fodder than moth bean, horsegram and pillipesera. But both intercrops yielded additional returns with cotton as compared to sole crop of cotton alone.

In conclusion, Net returns were significantly superior under intercropping system than $\mathrm{Bt}$ cotton + pillipesera intercropping system and sole cotton. The additional returns from the intercrop compensated the reduction in kapas yield. Among the four intercropping systems, cotton + fodder cowpea was more remunerative than other systems.

This was due to the lesser reduction in cotton yield and higher returns from green fodder 
yield. The net returns and BCR were higher when cotton was intercropped with fodder cowpea.

The result is in accordance with the findings of Krishnasamy et al., (1995); Chellaiah and Gopalaswamy (2000) and Wankhade et al., (2000).

\section{References}

Bhatt, J.G., T. Ramanujam, M.R.K. Rao and A.R.S. Nathan. 1982. A unified hormo nutritional concept of boll shedding in cotton. Turrialba, 32:59-65.

Chellaiah, N. and N. Gopalaswamy. 2000. Effect of intercropping and foliar nutrition on the productivity of summer irrigated cotton. Madras Agric, J., 87(4-6):267-270.

Gifford, R. M., and C.L. Jenkins. 1981. Prospects of applying knowledge of photosynthesis toward improving crop production. New York, Academic press, In Gorindjee, ed., Photosynthesis: $\mathrm{CO}_{2}$ Assimilation and Plant Productivity, 2.

Giri, A.N and Gore, S.B. 2006. Effect of plant densities and NPK levels on yield of newly released desi varieties cotton (Gossypium arboretum L.) J. Cotton Res. Develop., 20(1):77-79.

Guinn, G. 1982. Causes of square and boll shedding in cotton. USDA Tech. Bu., No. 1672. U.S. Gov. Print Office, Washington, DC.

Krishnasamy, S., A. Mohamed Ali and S. Manoharan. 1995. Productivity and profitability of intercropping in summer cotton and integrated nitrogen management. Madras Agric. J., 82(7-9):460-461.

Kumara Perumal, N. 1999. Effect of different nitrogen levels on morpho-physiological characters and yield in rainfed cotton. Indian J. Plant Physiol., 4:65-67.

Kumaraswamy, A.S. and M.M. Hosmani, 1978.
Intercropping in Varalaxmi cotton. Mysore J. Agric. Sci., 12:212-216.

Ram Prakash and Mangal Prasad. 2000. Effect of nitrogen, chlormequat chloride and farmyard manure applied to cotton (Gossypium hirsutum) and their residual effect on succeeding wheat (Triticum aestivaum) crop. Indain J. Agron., 45(2):263-268.

Ramanjaneyalu, A.V. and B. Bucha Reddy. 2002. Influence of intercropping and fertility management in hybrid cotton on total productivity and economics. ANGRAU J. Res., 30:105-11.

Ravindra Kumar, A.B. Turkhede, R.K. Nagar and Anil Nath. 2017. Effect of Different Intercrops on Growth and Yield Attributes of American Cotton under Dryland Condition. Int. J. Current Microbio. Applied Sci., 6(4):754-761.

Rochester, I.J., M.B. Peoples, N.R. Hulugalle, R.R. Gault and G.A. Constable. 2001. Use of legumes to enhance nitrogen fertility and soil condition in cotton cropping systems. Field Crops Res., 70:27-41.

Sagarka, A.B., D. D. Malavia, R.M. Solan, N.A. Kachot and B.M. Baabhi. 2002. Effect of irrigation methods and nitrogen on yield and quality of winter cotton (G. hirsutum) Indian J. Agron., 47(4):544-549.

Sreenivas, G. and K.V.K. Rao. 1999. Response of American cotton (Gossypium hirsutum L.) to nitrogen under rainfed conditions. J. Res. ANGRAU. 27: 81-83.

Sunitha, V., Chandrasekhar, $\mathrm{K}$ and Veeraraghavaiah, R. 2010. Performance of $B t$ cotton hybrids at different nitrogen levels. J. Cotton Res. Develop., 24(1):5255.

Wankhede, S.T., A.B. Tukhedo, V.M. Solanke, S.D. Malvi and R.N. Katkar. 2000. Effect of intercropping on yield of cotton. Crop Res., 19(3):409-413.

\section{How to cite this article:}

Daisy, M., K. Rajendran and Mohamed Amanullah, M. 2017. Effect of Legume Fodder Intercrops and Different Fertilizer Levels on Growth, Yield and Economics of Bt Cotton under Irrigated Condition. Int.J.Curr.Microbiol.App.Sci. 6(7): 2238-2243. doi: https://doi.org/10.20546/ijcmas.2017.607.324 